\title{
Biodiversity of freshwater fish of a protected river in India: comparison with unprotected habitat
}

\author{
Uttam Kumar Sarkar*, Ajey Kumar Pathak, Lalit Kumar Tyagi, Satyendra Mohan Srivastava, \\ Shri Prakash Singh \& Vineet Kumar Dubey \\ National Bureau of Fish Genetic Resources, Canal Ring Road, Dilkusha, Lucknow- 226002, India; usarkar1@ \\ rediffmail.com,nbfgr@sancharnet.in, akpathak@nbfgr.res.in, tyagi_1k@rediffmail.com, smsrivastava@nbfgr.res.in, \\ spsingh@nabfgr.res.in,vineet_dubey26@yahoo.co.in \\ * Corresponding author
}

Received 06-XII-2011. Corrected 30-IX-2012. Accepted 30-X-2012.

\begin{abstract}
In India, freshwater environments are experiencing serious threats to biodiversity, and there is an urgent priority for the search of alternative techniques to promote fish biodiversity conservation and management. With this aim, the present study was undertaken to assess the fish biodiversity within and outside a river protected area, and to evaluate whether the protected river area provides some benefits to riverine fish biodiversity. To assess this, the pattern of freshwater fish diversity was studied in river Gerua, along with some physicochemical conditions, from April 2000 to March 2004. For this, a comparison was made between a $15 \mathrm{~km}$ stretch of a protected area (Katerniaghat Wildlife Sanctuary), and an unprotected one $85 \mathrm{~km}$ downstream. In each site some physicochemical conditions were obtained, and fish were caught by normal gears and the diversity per site described. Our results showed that water temperature resulted warmest during the pre-monsoon season $\left(25^{\circ} \mathrm{C}\right)$ and low during the winter $\left(14-15^{\circ} \mathrm{C}\right)$; turbidity considerably varied by season. In the protected area, a total of 87 species belonging to eight orders, 22 families and 52 genera were collected; while a maximum of 59 species belonging to six orders, 20 families and 42 genera were recorded from the unprotected areas. Cyprinids were found to be the most dominant genera and Salmostoma bacaila was the most numerous species in the sanctuary area. Other numerous species were Eutropiichthys vacha, Notopterus notopterus, Clupisoma garua and Bagarius bagarius. The results indicated more species, greater abundances, larger individuals, and higher number of endangered fishes within the sanctuary area when compared to the unprotected area. Analysis on the mean abundance of endangered and vulnerable species for the evaluated areas in the sanctuary versus unprotected ones indicated significant differences in fish abundance $(p<0.05)$. These results showed that this riverine protected area could be important for conservation and management of fish diversity in the region, especially for resident and threatened species. Rev. Biol. Trop. 61 (1): 161-172. Epub 2013 March 01.
\end{abstract}

Key words: protected area, fish diversity, river Gerua, aquatic sanctuary, conservation, India.

Freshwater is critical to human society and sustains all terrestrial and aquatic ecosystems (Millennium Ecosystem Assessment 2005). Worldwide, freshwater fishes are the most diverse of all vertebrate groups, but are also the most highly threatened through anthropogenic activities such as river management works, dam building, and land use change in the watersheds (Duncan \& Lockwood 2001, Dudgeon et al. 2006, De Silva et al. 2007, Nel et al. 2009). Therefore, studies are being executed to develop tools for freshwater biodiversity conservation (Margules \& Pressey 2000, Saunders et al. 2002, Moilanen et al. 2008), and various methods and strategies have been proposed (Dugan et al. 2002, Suski \& Cooke 2007). The need to protected freshwater habitats, rare or endangered species, and intact waterways have been widely justified (Lake 1980, Moyle \& Sato 1991, Sarkar et al. 2008).

India has developed a network of 605 protected areas covering approximately $4.74 \%$ of 
the total geographical area of the country in the form of 509 wildlife sanctuaries, 96 National Parks, and three conservation reserves under "Wild life (Protection) Act" (NBAP 2008). The total protected areas have been earmarked for extensive conservation of habitats and ecosystems. However, a review of the protected area network in India reveals a poor representation of freshwater fish biodiversity in that network. Recently, the Ministry of Environment and Forests, Government of India, has prepared National Biodiversity Action Plan to help conserving biological diversity in both terrestrial and aquatic ecosystems (MOEF 2008). India has very rich aquatic biodiversity spanning the country. In India there is about 2319 fish species that have so far been documented, of which about 838 fishes inhabit freshwaters (Lakra \& Sarkar 2010).

The Gerua River originates in the Himalayan mountains, crosses through the Royal Bardi National Park in Nepal, and enters India at the Katerniaghat Wildlife Sanctuary (listed as the Kateraniaghat Pashu Vihar Sanctuary by the United Nations Environment Programme 2005) in the Terai region, Bahraich district, Uttar Pradesh. The River is largę with a mean annual discharge near $1500 \mathrm{~m}^{3} / \mathrm{s}$ (Agrawala et al. 2003). The width of the river channel varies considerably with location, discharge, and the number of channels on a cross section. The presence of protected area on the upper stretch and forest cover on the mid stretch of river tend to have positive impact on its aquatic habitat. No major degradation of the habitat exists within the sanctuary, except occasional secretive use of insecticides by local fishermen, illegal poaching, fishing by small mesh and large catches of fish by the contractors in the buffer area of the sanctuary. Downstream of the sanctuary, the Girijapuri Barrage diverts some of the water flow of Gerua River for irrigation and then joins the Ghagra River, which is one of the major tributary of River Ganges.

In India, studies on freshwater fishes in rivers were primarily focused on the catch data of fishes of commercial value (Vishwanath et al. 1998, Sarkar \& Bain 2007, Raghavan et al. 2008, Sarkar et al. 2010). A review of published literature shows that very few studies on fish diversity have been completed in India (Biju et al. 1999, Sarkar \& Bain 2007, Sarkar et al. 2008). Besides, conservation information on the pattern of fish biodiversity, abundance of threatened and endangered fishes, and threats in the rivers and streams are very limited in India (Husain 1983, Sarkar et al. 2010, Lakra et al. 2010). Nevertheless, recently, it has been observed to decline rapidly due to environmental degradation like urbanization, damming, abstraction of waters for irrigation and power generation, and pollution. These environmental impacts have induced severe stress on freshwater fish diversity (Sarkar et al. 2008). In view of the worldwide significance of Indian freshwater fishes, effective planning for conservation and management strategies are now important and a pressing challenge. The objectives of this study were to evaluate fish species diversity, composition, individual sizes, habitat, and threats within and outside a river protected area. Our purpose was also to assess whether this protected river area provides benefits to freshwater fishes so that this concept can be used further in India and other developing countries.

\section{MATERIALS AND METHODS}

Study site: The studies were made in two section of the river Gerua. One section of $15 \mathrm{~km}$ stretch within the Katraniaghat Wildlife Sanctuary (28 20 -' $^{\circ} 2.54^{\prime \prime} \mathrm{N}$ and $81^{\circ} 06-{ }^{\prime}$ '57.76" E to $28^{\circ} 22-' 11.27^{\prime \prime} \mathrm{N}$ and $81^{\circ} 12$-' $^{\prime} 6^{\prime \prime} \mathrm{E}$ ). The second section of $85 \mathrm{~km}$ stretch belonged to a downstream unprotected area. In the protected area, most of the sampling sites were shaded by dense riparian vegetation. The surrounding land in the sanctuary is protected for conservation purposes and is composed of grasslands, deep forest, terrestrial wild animals and marshy lowlands. The unprotected sites were mainly composed of agricultural land use pattern, rural hamlets with relatively less riparian vegetation. 
Field sampling and analysis: The field portion of the study started in April 2000 and continued until March 2004. Field sampling was done annually by the seasons: pre-monsoon (March-May), monsoon (June-September), and winter (October-February). Fishes were collected from nine sampling sites identified as S1 to S9; four sites within sanctuary, and five sites outside this protected area (Fig. 1). Fishing is prohibited in all sanctuary sites although some poaching was observed, nevertheless, it was very common outside the sanctuary. The sampling sites (approximately $200 \mathrm{~m}$ long) were selected in upstream, midstream, and downstream areas within the sanctuary and outside the protected area. Sites were selected to include multiple representative habitats: mid-channel, shoreline, run and riffle, small channels and wetlands connected ditches, shallow ponds, and pools. Habitat features measured were: water depth $(\mathrm{m})$, water temperature $\left({ }^{\circ} \mathrm{C}\right)$, transparency $(\mathrm{cm})$, water flow $(\mathrm{km} / \mathrm{hr})$, conductivity $(\mu \mathrm{S} / \mathrm{cm})$. Water depth was the average of seven to 10 measurements covering the channel portion of the sampling site at the time of sampling. Water temperature and conductivity were measured by Cyber Scan Waterproof PC 300 multiparameter equipment.

Fishes were collected with gill nets (mesh $2.5 \times 2.5 \mathrm{~cm} ; 3 \times 3 \mathrm{~cm} ; 7 \times 7 \mathrm{~cm} ;$ length $\mathrm{x}$ breadth $=75 \times 1.3 \mathrm{~m}, 50 \times 1 \mathrm{~m}$, and $30 \times 1 \mathrm{~m})$. At each site, a standard set of gill nets was deployed overnight (17:00-07:00h) and fishing was carried out by using the expertise of local fisher folks. To confirm whether all the species of fish were collected from gill nets, additional data was obtained on number of occasions from the local markets, where fish were sold, and look after the presence of any species that were caught by variety of gears (traps, harpoons, hooked lines, cast nets, among others). Unless collected directly from the source, the habitat

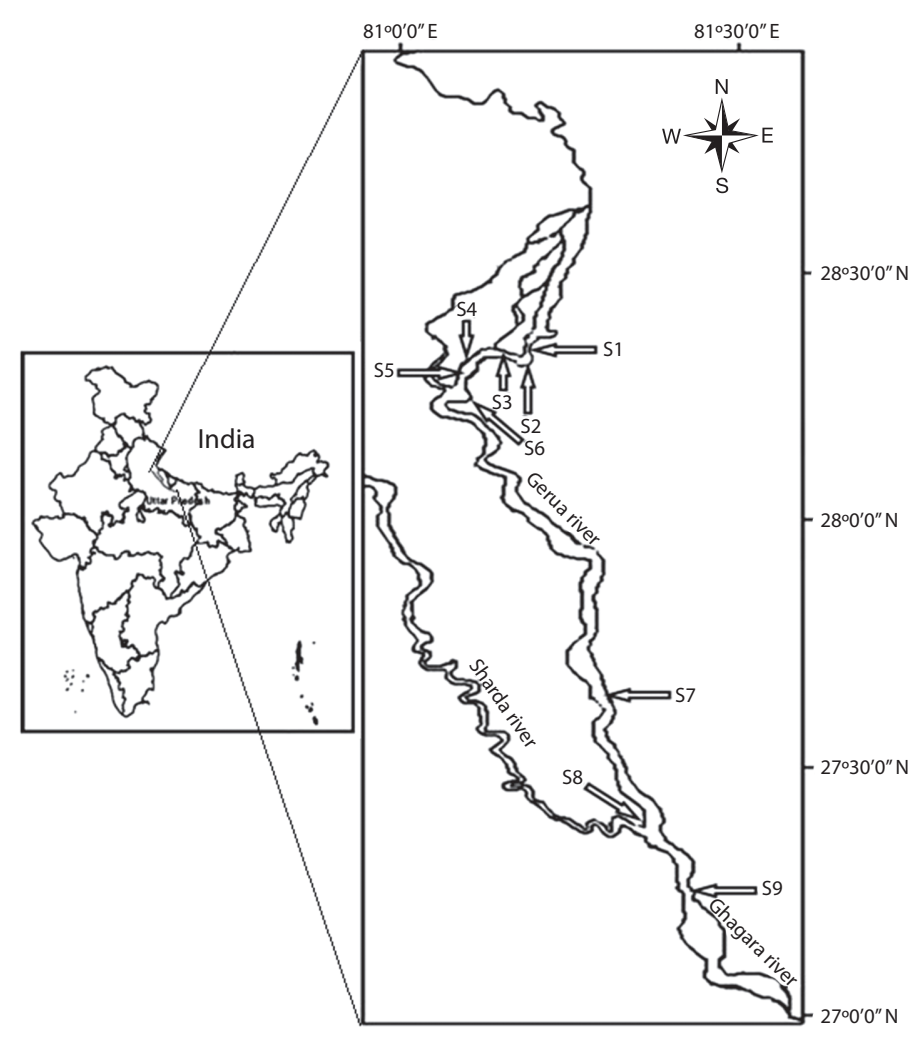

Fig. 1. River Gerua showing sampling sites (S1-S9). 
from which the fish originated was not traced, no quantification of fish abundance data was attempted for any of these additional sources, since reliable information was usually not available. All specimens collected were identified using the classification system of Talwar \& Jhingran (1991). Any color, spots, maximum size and other characters of the fishes caught were recorded. Fish samples were preserved in $10 \%$ formalin solution.

Species relative abundance (RA) in the catch was computed by the following formula:

$$
\mathrm{RA}=\mathrm{N} / \mathrm{S}
$$

Where:

$\mathrm{N}=$ Total number of individuals of specific species

$\mathrm{S}=$ Total number of all fishes

The species diversity index was calculated using the Shannon-Weiner Information Function (Shannon \& Wiener 1963):

$$
\mathrm{H}=\sum\left(\mathrm{n}_{\mathrm{i}} / \mathrm{N}\right) \log _{2}\left(\mathrm{n}_{\mathrm{i}} / \mathrm{N}\right)
$$

Where:

$\mathrm{n}_{\mathrm{i}}=$ total number of individuals of specific species

$\mathrm{N}=$ total number of individuals of all species

We used Jacquard's index to compare the similarity of the species in the sampling sites within the sanctuary and outside:

$$
\mathrm{Sj}=\mathrm{j} /(\mathrm{x}+\mathrm{y}-\mathrm{j})
$$

Where:

$\mathrm{Sj}$ is the similarity between any two zones $\mathrm{X}$ and $\mathrm{Y}$

$\mathrm{j}$ the number of species common to both the zones $\mathrm{X}$ and $\mathrm{Y}$

$\mathrm{X}$ the total number of species in zone $\mathrm{X}$ and $\mathrm{Y}$

The similarity in species composition within the sanctuary and unprotected area of the Gerua River was obtained from the Jacquard's index similarity coefficients generated by using the EstimatesS (version 5.0.1) software (Colwell 1997).

A data matrix was constructed with presence and absence of fish species for each of the sampling sites in the sanctuary and unprotected areas. Analysis of variance was conducted to test the presence and abundance of fish species across the sampling sites. We used the Duncan's new multiple range test to identify the sites that differed, and calculations were performed using SPSS software package (SPSS 2006). References to conservation status categories within this paper (endangered species, vulnerable species among others) are based on CAMP (1998) and IUCN (2010). Data regarding threats faced by the fish fauna within the sanctuary and unprotected river areas were obtained from direct observations and interactions with local stakeholders and fisherman.

\section{RESULTS}

Physicochemical environment: There were physicochemical environmental attributes that showed little variation over season and river reach, and there were some that varied considerably. Table 1 presents mean values and standard deviations across seasons and sites in the sanctuary and unprotected sites. Hydrogen ion concentration $(\mathrm{pH})$ was rather stable across seasons and river sites in the sanctuary and unprotected reaches. The $\mathrm{pH}$ across seasons varied slightly (7.0-7.8), and mean $\mathrm{pH}$ value in the sanctuary was similar (7.4) to unprotected sites (7.3). Likewise, conductivity recorded in the sanctuary area varied from $201-239 \mu \mathrm{S} /$ $\mathrm{cm}$ across seasons and was slightly higher in winter. In the unprotected area, conductivity was observed between $201-220 \mu \mathrm{S} / \mathrm{cm}$ across seasons and again it was higher in winter. The sanctuary river water was very similar (mean $217 \mu \mathrm{S} / \mathrm{cm}$ ) to the unprotected river water $(210 \mu \mathrm{S} / \mathrm{cm})$. Air temperature did not vary much between sites in the sanctuary $\left(28^{\circ} \mathrm{C}\right)$ and unprotected sites $\left(26^{\circ} \mathrm{C}\right)$. However, through the air temperatures were warm $\left(28-26^{\circ} \mathrm{C}\right)$ premonsoon and monsoon seasons and dropped much lower in winter $\left(16-19^{\circ} \mathrm{C}\right)$. 
TABLE 1

Habitat characteristics of protected and unprotected sites of the River Gerua

\begin{tabular}{lcccccc}
\multicolumn{1}{c}{ Parameters } & \multicolumn{3}{c}{ Protected } & \multicolumn{3}{c}{ Unprotected } \\
& Premonsoon & Monsoon & Winter & Premonsoon & Monsoon & Winter \\
$\mathrm{pH}$ & $7.5 \pm 0.2$ & $7.8 \pm 0.2$ & $7.05 \pm 0.04$ & $7.03 \pm 0.1$ & $7.3 \pm 0.4$ & $7.68 \pm 0.5$ \\
Water temperature $\left({ }^{\circ} \mathrm{C}\right)$ & $25.1 \pm 0.8$ & $20.7 \pm 2$ & $13.53 \pm 2.3$ & $24.66 \pm 1.5$ & $22.45 \pm 2.8$ & $15.3 \pm 3$ \\
Air temperature $\left({ }^{\circ} \mathrm{C}\right)$ & $28.16 \pm 1.6$ & $28.03 \pm 0.4$ & $15.7 \pm 3$ & $26.5 \pm 1.3$ & $25.96 \pm 2.6$ & $18.8 \pm 3.4$ \\
Turbidity $(\mathrm{cm})$ & $18.33 \pm 11.2$ & $2.3 \pm 0.7$ & $28.0 \pm 2.6$ & $40.96 \pm 28.7$ & $15.46 \pm 12.9$ & $50 \pm 31.1$ \\
Conductivity $(\mu \mathrm{S} / \mathrm{cm})$ & $200.86 \pm 8.5$ & $210.83 \pm 10.3$ & $238.7 \pm 11.9$ & $208.33 \pm 16$ & $201 \pm 12.5$ & $219.8 \pm 33.9$ \\
Depth $(\mathrm{m})$ & $4.33 \pm 2.6$ & $9.66 \pm 1$ & $5.63 \pm 3.4$ & $1.1 \pm 0.03$ & $1.86 \pm 0.9$ & $1.28 \pm 0.08$ \\
Water velocity $(\mathrm{km} / \mathrm{h})$ & $14.9 \pm 4.2$ & $9.30 \pm 4.8$ & $2.93 \pm 0.2$ & $11.3 \pm 3.5$ & $12.02 \pm 6$ & $12.66 \pm 2.3$ \\
\hline
\end{tabular}

Data include: Means and standard deviation values.

Water temperature was warmest during the premonsoon season $\left(25^{\circ} \mathrm{C}\right)$, cooled some in monsoon season $\left(21-22^{\circ} \mathrm{C}\right)$, and declined during the winter $\left(14-15^{\circ} \mathrm{C}\right)$. Turbidity varied by season considerably with the monsoon season with lowest transparency $(2-15 \mathrm{~cm})$ with downstream sites being the most transparent. Other season had much clearer water $(18-50 \mathrm{~cm})$ with the clearest water downstream of the sanctuary. There was clearly deeper water in the sanctuary (4-10m) compared to the unprotected sites (1-2m). Both river sections observed deeper water column during the monsoon season due to greater river flows. Current velocity in the sanctuary area varied from slow $(2.93 \mathrm{~cm} / \mathrm{s})$ to moderately swift $(14.9 \mathrm{~cm} / \mathrm{s})$ across seasons. In the unprotected river velocity were higher than the sanctuary waters, and ranged from $11-13 \mathrm{~cm} / \mathrm{s}$. However, water depth was much shallower and expected cross section area was much less. That may explain the differences between the sanctuary and unprotected river in terms of current velocity.

Fish communities across sites: A total of 6220 fish were collected from the sanctuary river waters and unprotected river sites, and there were 87 species representing 22 families and 52 genera. The Cyprinidae was the dominant family with 40 species consisting almost half (49\%) of all fishes collected. Following, the family Bagridae had seven species and $8 \%$ of all fish collected. Then, the Schilbeidae had five species represented $6 \%$ of all fish collected. Overall, the most numerous species was a Cyprinid Salmostoma bacaila in terms of relative abundance (RA) with $11 \%$ and 1113 individuals. The next most numerous were the Schilbeid Eutropiichthys vacha (8\%), Notopterid Notopterus notopterus (6\%), Schilbeid Clupisoma garua (5\%) and Sisorid Bagarius bagarius (5\%). While the relative abundance of two Indian major carps, Catla catla and Labeo rohita, was relatively low $(<1.5 \%)$. However, a bottom dwelling Indian major carp Cirrhinus mrigala was more abundant (2\%).

In the collections, there was an abundance of threatened fishes (3 848 individuals, 28 species) like Chitala chitala, Notopterus notopterus, Ompok bimaculatus, Bagarius bagarius, Tor putitora, Tor tor, Eutropiicthys vacha, Pangasius pangasius and others (Fig. 2). In this study, 28 endangered and vulnerable species by Indian classifications (National Bureau of Fish Genetic Resources, 1998) constituted almost of third (31\%) of the fish collected (Table 2). Under conservation status as per IUCN (2010) two species (Schizothorax richardsonii and Tor putitora) were categorized as endangered, seven species were near threatened, 10 under least concern, and one species under data deficient. Among minor carps, Labeo bata and Cirrhinus reba showed higher relative abundance. Among exotic species, Cyprinus carpio was recorded inside the sanctuary. 
TABLE 2

List of threatened fish species recorded in the sanctuary (S1-S4) and unprotected (S5-S9) sites

\begin{tabular}{|c|c|c|c|c|c|c|c|c|c|c|}
\hline \multirow{2}{*}{ Family and species } & \multirow{2}{*}{$\begin{array}{l}\text { Threatened category } \\
\text { (NBFGR/IUCN) }\end{array}$} & \multicolumn{4}{|c|}{ Protected area } & \multicolumn{5}{|c|}{ Unprotected area } \\
\hline & & S1 & $\mathrm{S} 2$ & $\mathrm{~S} 3$ & S4 & S5 & S6 & S7 & S8 & S9 \\
\hline \multicolumn{11}{|l|}{ Notopteridae } \\
\hline Chitala chitala & EN/NT & NA & A & A & A & NA & A & A & A & NA \\
\hline \multicolumn{11}{|l|}{ Cyprinidae } \\
\hline Barilius barila & VU/LC & NA & NA & A & A & A & A & A & NA & NA \\
\hline Catla catla & VU/NE & NA & NA & A & $\mathrm{A}$ & A & A & A & A & NA \\
\hline Cirrhinus reba & $\mathrm{VU} / \mathrm{NE}$ & NA & NA & NA & NA & NA & A & NA & NA & NA \\
\hline Gara gotyla gotyla & $\mathrm{VU} / \mathrm{NE}$ & A & NA & A & NA & A & NA & NA & NA & NA \\
\hline Labeo dero & VU/LC & $\mathrm{A}$ & A & A & NA & A & NA & NA & NA & NA \\
\hline Labeo dyocheilus & VU/LC & NA & A & A & A & A & NA & NA & NA & NA \\
\hline Puntius conchonius & VU/LC & NA & NA & NA & A & NA & A & A & A & NA \\
\hline Puntius sarana & $\mathrm{VU} / \mathrm{LC}$ & A & NA & A & A & NA & A & A & A & NA \\
\hline Raimas bola & VU/NE & NA & NA & NA & A & NA & NA & NA & NA & NA \\
\hline Schizothorax richardsonii & VU/EN & A & NA & NA & A & A & NA & NA & NA & NA \\
\hline Tor putitora & $\mathrm{EN} / \mathrm{EN}$ & A & NA & A & A & NA & NA & NA & NA & NA \\
\hline Tor tor & $\mathrm{EN} / \mathrm{NT}$ & NA & NA & A & A & NA & NA & NA & NA & NA \\
\hline \multicolumn{11}{|l|}{ Cobitidae } \\
\hline Botia lohachata & $\mathrm{EN} / \mathrm{NE}$ & NA & A & NA & NA & A & NA & NA & NA & NA \\
\hline \multicolumn{11}{|l|}{ Bagridae } \\
\hline Mystus vittatus & VU/LC & NA & NA & A & NA & NA & A & $\mathrm{A}$ & A & A \\
\hline \multicolumn{11}{|l|}{ Siluridae } \\
\hline Ompok bimaculatus & $\mathrm{EN} / \mathrm{NT}$ & NA & A & A & A & NA & A & A & A & NA \\
\hline Ompok pabda & $\mathrm{EN} / \mathrm{NT}$ & NA & NA & NA & A & NA & $\mathrm{A}$ & $\mathrm{A}$ & A & NA \\
\hline Ompok pabo & VU/NT & NA & A & NA & NA & NA & A & A & A & NA \\
\hline \multicolumn{11}{|l|}{ Schilbeidae } \\
\hline Ailia coila & VU/NT & A & A & A & A & NA & A & A & NA & NA \\
\hline Eutropiichthys vacha & $\mathrm{EN} / \mathrm{LC}$ & A & A & A & A & A & $\mathrm{A}$ & A & A & A \\
\hline Pseudeutropius atherinoides & EN/NE & $\mathrm{A}$ & NA & A & $\mathrm{A}$ & NA & NA & NA & NA & NA \\
\hline Clupisoma garua & VU/LC & A & A & A & A & A & $\mathrm{A}$ & $\mathrm{A}$ & A & A \\
\hline \multicolumn{11}{|l|}{ Pangasiidae } \\
\hline Pangasius pangasius & $\mathrm{CR} / \mathrm{LC}$ & NA & NA & NA & NA & NA & A & NA & NA & NA \\
\hline \multicolumn{11}{|l|}{ Sisoridae } \\
\hline Bagarius bagarius & VU/NT & $\mathrm{A}$ & A & A & A & A & A & A & A & A \\
\hline \multicolumn{11}{|l|}{ Claridae } \\
\hline Clarias batrachus & $\mathrm{VU} / \mathrm{NE}$ & NA & A & NA & A & NA & A & A & A & NA \\
\hline \multicolumn{11}{|l|}{ Heteropneustidae } \\
\hline Heteropneustes fossilis & VU/LC & NA & A & A & A & NA & $\mathrm{A}$ & NA & NA & NA \\
\hline \multicolumn{11}{|l|}{ Anabantidae } \\
\hline Anabas testudineus & VU/DD & A & NA & A & A & NA & NA & A & NA & NA \\
\hline \multicolumn{11}{|l|}{ Channidae } \\
\hline Channa orientalis & $\mathrm{VU} / \mathrm{NE}$ & NA & A & A & A & NA & A & A & A & A \\
\hline
\end{tabular}

$\mathrm{EN}=$ Endangered, $\mathrm{VU}=$ Vulnerable, $\mathrm{NT}=\mathrm{Near}$ threatened, $\mathrm{LC}=$ Least concerned, $\mathrm{CR}=\mathrm{Critically}$ endangered, $\mathrm{DD}=\mathrm{Data}$ deficient, NE=Not evaluated. 


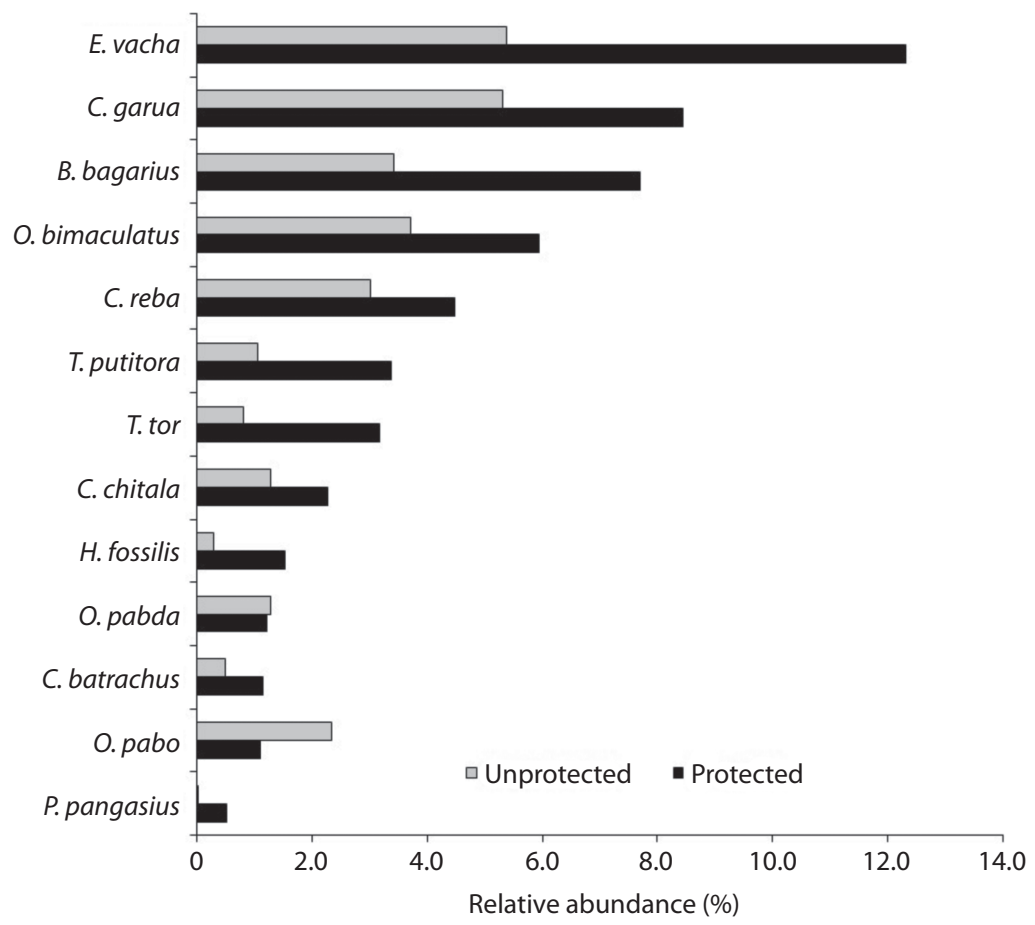

Fig. 2. Comparative relative abundance (\%) of selected threatened species listed as endangered, vulnerable and near threatened categories based on NBFGR (1998) and IUCN (2010).

Of the 87 species recorded from the sanctuary river waters, 12 species $(14 \%)$ that are oriented to coolwater habitat, 46 species $(53 \%)$ are warmwater and also recognized as food fish, 13 species $(15 \%)$ as good aquarium fishes, and 4 species $(5 \%)$ considered as high profile game fishes in India (Tor tor, T. putitora, Aorichthys aor and Bagarius bagarius). The study also showed new record in maximum length of six freshwater fish species: Notopterus notopterus $(35 \mathrm{~cm})$, Gudusia chapra $(20 \mathrm{~cm})$, Barilius barila $(13 \mathrm{~cm})$, Ompok pabo $(28 \mathrm{~cm})$, Xenentodon cancila $(31.5 \mathrm{~cm})$ and Salmostoma bacaila $(20.5 \mathrm{~cm})$.

The Shannon-Weiner diversity index across all sites in the sanctuary ranged between 3.8-5.2 with a mean of 4.4 as compared to 2.9-4.8 with a mean of 4.2 at sites that were in unprotected areas (Table 3). The Mann-Whitney test of the Shannon-Weiner diversity index values between the sanctuary sites and unprotected sites were non-significant $(\mathrm{p}=0.63)$. The Jacqard's similarity index in the sites of protected and unprotected areas showed more similarity across the sites regardless if they were in sanctuary waters or unprotected waters.

Comparison between sanctuary river sites and unprotected sites: In this study, diversity of freshwater fish in the study area showed a considerable difference between the sanctuary and unprotected river sites (Table $3)$. Among four sites studied in the sanctuary, site S4 had the maximum diversity in terms of species (65) and genera (45) and site S2 had the lowest (28 species and 21 genera). In the unprotected river, site $\mathrm{S} 7$ had the maximum diversity (55 species and 44 genera) and site S9 had the lowest (17 species and 12 genera). Genera like Labeo (8 species) and Puntius (7 species) were dominated in the protected area followed by unprotected area ( 7 and 6 species). 
TABLE 3

Fish diversity, index of fish diversity with mean values for the sites in sanctuary and unprotected area

\begin{tabular}{|c|c|c|c|c|}
\hline Category & Sampling sites & N. ${ }^{\circ}$ of species & N. ${ }^{\circ}$ of genera & Shannon-Weiner diversity index \\
\hline \multirow[t]{4}{*}{ Protected } & $\mathrm{S} 1$ & 30 & 22 & 4.39 \\
\hline & $\mathrm{S} 2$ & 28 & 21 & 3.87 \\
\hline & $\mathrm{S} 3$ & 47 & 35 & 4.33 \\
\hline & $\mathrm{S} 4$ & 65 & 45 & 5.17 \\
\hline Mean \pm SD & & $42.5 \pm 17.25$ & $30.75 \pm 11.44$ & $4.45 \pm 0.54$ \\
\hline \multirow[t]{5}{*}{ Unprotected } & S5 & 36 & 27 & 4.30 \\
\hline & S6 & 50 & 43 & 4.67 \\
\hline & S7 & 55 & 44 & 4.84 \\
\hline & S8 & 38 & 25 & 4.37 \\
\hline & S9 & 17 & 12 & 2.92 \\
\hline Mean \pm SD & & $39.2 \pm 14.75$ & $30.2 \pm 13.44$ & $4.22 \pm 0.76$ \\
\hline
\end{tabular}

Within the sanctuary three sites $(\mathrm{S} 1, \mathrm{~S} 2$, S4) were distinct in fish composition while for the unprotected sites two were unique (S8, S9).

This study showed a distinct variation $(p<0.05)$ in the relative abundance of 13 threatened fish species in the sanctuary sites and unprotected sites (Fig. 2). Many of the threatened fishes were found abundant in the sanctuary areas than the unprotected areas. Fish species like, E. vacha, C. gerua followed by $B$. bagarius, O. bimaculatus, C. reba, T. tor and T. putitora were the most abundant species in both protected and unprotected areas. In the unprotected areas, species like $O$. pabda and $O$. pabo were recorded quite higher in abundance than the protected areas.

\section{DISCUSSION}

In the present study, the diversity of species in the protected and unprotected areas varied considerably from site S1 to S9. On comparison, it was found that all the sites in the protected areas not necessarily showed rich fish diversity than the sites located in the unprotected areas. This variation is of high interest depending on the site specific habitat characteristics. For instance, the river habitat in the sanctuary area at sites S3 and S4 was highly diverse including a network of small channels, wetlands, presence of instream structures (undercut banks, woody logs and debris, overhanging vegetation, among others), and dense riparian vegetation which could be greatly responsible for high species diversity. Moreover, these sites were located downstream from a barrage forming larger pool habitats supporting fishes to accumulate in certain habitats. Low human disruption and maintenance of ecological integrity in the sanctuary area can be another reason for more diversity and fish abundance. However, sites that did not follow the same pattern might be attributed to fast free flowing river water (site $1 \& 2$ ) which prevents fishes for accumulating in certain habitats.

In the present study, water depth was clearly deeper in the sanctuary area as compared to the unprotected sites. In flowing waters the number of fish species were more numerous with increasing water depth (Sheldon 1968, Bain 1995). Sarkar \& Bain (2007) analysed habitat relationships in River Gerua at the sanctuary site, and found three grouped fish species occupying distinct habitats. The deepest habitat had the highest species diversity. Large rivers differ from small streams in several attributes like lack of light penetration to bed, greater depths and velocities on average, greater ratio of volume to margins, and greater physical stability (Dunne \& Leopold 1978). Deeper habitats can influence fish species diversity and abundance in the Gerua River. Finally, unprotected sites are known to have higher fishing intensity. When a river is in a sanctuary setting there are a number effects that come with protection of human activities, and it 
could be hard to pinpoint the cause of increased diversity and abundance.

As described earlier, the diversity of a certain site in the studied river does not directly depends on the protected area boundaries, and can be reflected in rich species diversity of sites S6 and S7 of the unprotected areas; this could be attributed to site specific suitable environmental conditions. In addition, these sites were seen in supporting large group of macrophytes which diversify aquatic habitats and provide support for more fish and greater numbers (Growns \& Gehrke 2003, Sarkar et al. 2008, 2010). In contrast, the minimum species diversity at $\mathrm{S} 9$ might be due to more distance from the protected area, effect of sedimentation, loss of breeding and spawning grounds, and over harvesting. Loss and reduction in diversity and abundance of fishes were consistent with and declining water quality and loss of habitats as a cause of human activities. Fish communities in riverine systems typically follow a pattern of increasing species diversity and abundance from upstream to downstream (Bayley \& Li 1994). We documented a contrasting, inverse relation for species diversity and abundance downstream direction on the river.

The Shannon-Weiner diversity index of the sites within sanctuary and unprotected sites slightly differed from S1 to S8, and considerable difference was observed in S9. This site indicated the maximum effect of protection because it was the furthest from the sanctuary. The Jacqard's index showed the site wise differentiation in species composition in the protected and unprotected areas. The possible reason of low similarity index in the unprotected areas might be the differences of the land use pattern, high sedimentation rate, suburban communal sewage, overfishing, and agricultural runoff. Paller et al. (2000) found higher minor variation in Jacqard's index among the undisturbed sites, while Jacqard's index was low at the disturbed site. This pattern is consistent with Paller et al. (2000).

Most importantly, the relative abundance of threatened fishes listed as endangered and vulnerable within the sanctuary and unprotected sites differed significantly. This might be due to differences in the land use pattern, intensity of human interference, turbidity, depth, water flow, wind, and differences in fish life histories (Mosquera et al. 2000). However, many factors are involved and real benefit of the protection has many consequences for the habitat and the river. This finding is consistent with the study by McClanahan \& Kaunda (1996) that also found higher fish abundances inside than outside protected areas.

The composition of 12 endangered freshwater fishes at sites in the sanctuary and unprotected area were relatively heterogeneous. Three of endangered fishes (B. bagarius, C. gerua and E. vacha) were present at all the sites including the unprotected area indicating long range of distribution. The endangered mahseer, T. putitora and T. tor, exhibited a restricted range of distribution in the unprotected sites. A migratory large catfish, P. pangasius, was present at single location (S6) which is located nearest to the sanctuary area, indicating need of special conservation planning for this species. The present study also showed distinct variation in distribution pattern, size classes and abundance of the migratory species like $B$. bagarius, T. tor, P. pangassius, $W$. attu, $S$. silondia and $C$. chitala. In the sanctuary a unique behavior was observed with the Feather back, C. chitala, which showed frequent sightings in the river with river dolphins (Platanista gangetica gangetica).

This study recorded maximum length values (TL) that exceeded the earlier records for six freshwater fishes (Talwar \& Jhingran 1991), indicating that the protection of habitat can influence on fish length attainment. This study showed, with more species, greater abundances and larger individuals, and additionally showed higher number and densities of endangered fishes within the sanctuary area. Sarkar et al. 2007 reported a record size ( $22.5 \mathrm{~cm} \mathrm{TL})$ of clupeid (Gudusia chapra) from another protected area. In the protected river, there are other studies which recorded higher abundances of fish (Mosquera et al. 2000), greater sizes of individuals (Moyle \& Sato 
1991), Bayle-Sempere \& Ramos-Espla 1993, Dufour et al. 1995), and greater biomass (Francour 1991).

This study is the first of its kind for the River Gerua in India which showed that a protected area is an effective tool that can benefit freshwater fish conservation, including species with high conservation value. This conclusion is new because the role of protected areas has been shown to benefits river habitats, rare and endangered species, and intact river systems (Saunders et al. 2002, Lake 1980, Sarkar et al. 2008, Allan \& Flecker 1993, Braun et al. 2000, Saunders et al. 2002).

In conclusion, it is found that freshwater protected areas commonly result in increased fish abundances for those threatened fishes which are extremely important for biodiversity conservation and management. Our observations also indicated that these areas, within wildlife sanctuaries, can be used as freshwater aquatic sanctuary (FAS), if additional measures are taken to protect these aquatic resources against actual threats.

\section{ACKNOWLEDGMENTS}

We thank Director, NBFGR for providing necessary facilities and guidance. Authors are indebted to Chief Wildlife Warden, Department of Forest, Govt. of Uttar Pradesh, India for providing necessary permission to carry out survey and encouragements to carrying out the research work. We are grateful to Divisional Forest Officer, Katerniaghat Wild Life Sanctuary, Baharaich, Uttar Pradesh, India for his all sorts of help in carrying out inventory within sanctuary.

\section{RESUMEN}

En India los ambientes de agua dulce están experimentando una grave amenaza para la biodiversidad; ante esto es urgente investigar técnicas alternativas que promuevan la biodiversidad y manejo de los peces. El presente estudio se realizó con el objetivo de evaluar la biodiversidad de los peces dentro y fuera del área protegida del río Gerua, India, para evaluar si el área protegida provee beneficios a la biodiversidad de los peces fluviales.
Para evaluar el patrón de diversidad de los peces de agua dulce y las condiciones físico-químicas se estudió el río entre abril 2000 y marzo 2004. Se realizó una comparación en un tramo de $15 \mathrm{~km}$ de un área protegida (Santuario de Vida Silvestre Katerniaghat) y un tramo sin protección de $85 \mathrm{~km}$ aguas abajo. En cada sitio se obtuvieron algunas variables fisicoquímicas, los peces fueron capturados con varias artes de pesca y se describió la diversidad por sitio. Nuestros resultados mostraron que la temperatura del agua es mayor como resultado de la temporada de pre-monzón $\left(25^{\circ} \mathrm{C}\right)$ y menor durante el invierno $\left(14-15^{\circ} \mathrm{C}\right)$, la turbidez varía considerablemente según la temporada. En el área protegida, se recolectaron un total de 87 especies pertenecientes a ocho órdenes, 22 familias y 52 géneros, mientras que un máximo de 59 especies pertenecientes a seis órdenes, 20 familias y 42 géneros se registraron en las áreas no protegidas. El género más abundante pertenece a los Ciprínidos y Salmostoma bacaila fue la especie más abundante en el área del santuario. Otras especies numerosas fueron: Eutropiichthys vacha, Notopterus notopterus, Clupisoma garúa y Bagarius bagarius. Los resultados indicaron más especies, mayores abundancias, individuos más grandes y mayor número de peces con categoría de peligro de extinción dentro del área del santuario cuando se compara con la zona no protegida. El análisis de la abundancia promedio de peces en peligro de extinción y vulnerables de las áreas evaluadas en el santuario frente a las desprotegidos indicó diferencias significativas $(\mathrm{p}<0.05)$. Los resultados mostraron que esta área protegida ribereña podría ser importante para la conservación y manejo de la diversidad de los peces en la región, especialmente para los residentes y las especies amenazadas.

Palabras clave: área protegida, diversidad de peces, Río Gerua, Santuario acuático, conservación, India.

\section{REFERENCES}

Allan, J.D. \& A.S. Flecker. 1993. Biodiversity conservation in running waters: identifying the major factors that threaten destruction of riverine species and ecosystems. Bioscience 43: 33-43.

Agrawala, S., V. Raksakulthai, M. van Aalst, P. Larsen, J. Smith \& J. Reynolds. 2003. Development and climate change in Nepal: Focus on water resources and hydropower. Environment Directorate, Paris, France.

Bain, M.B. 1995. Habitat at the local scale: multivariate patterns for stream fishes. Bull. Français de la Pêche et la Piscicult 337/338/339:165-177.

Bayley, P.O. \& H. Li. 1994. Riverine fisheries, p. 251-281. In P. Calow \& G.E. Petts (eds.). The river handbook: hydrological and ecological principles. Blackwell, Boston, USA.

Bayle-Sempere, J.T. \& A. Ramos-Espla. 1993. Some population parameters as bioindicators to assess the 
'reserve effect' on the fish assemblage, p. 189-214. In C.F. Boudouresque, M. Avon \& C. Pergent-Martini (eds.). Qualité du milieu marin-Indicateurs biologiques et physicochimiques. GIS Posidonie Publ., Marseille, France.

Braun, D.P., L.B Bach, K.A. Ciruna \& A.T. Warner. 2000. Watershed-scale abatement of threats to freshwater biodiversity: the Nature Conservancy's freshwater initiative. Proceeding of the Water Environment Federation, Vancouver, Canada.

Biju, C.R., K. Raju Thomas \& C.R. Ajithkumar. 1999. Fishes of Parambikulam Wild Life Sanctuary, Palakkad District, Kerala. J. Bombay Nat. Hist. Soc. 96: 82-86.

Colwell, R.K. 1997. User's guide to EstimateS 5: statistical estimation of species richness and shared species from samples. Version 5.0.1. University of Connecticut, Storrs, USA.

De Silva, S.S., W. Abery Nigel \& T.T. Nguyen Thury. 2007. Endemic freshwater finfish of Asia: distribution and conservation status. Divers. Distrib. 13: 172-184.

Dugan, P.J., E. Baran, R. Tharme, M. Prein, M. Ahmed, P. Amerasinghe, C. Brown, M. Dey, G. Jayasinghe \& M. Niasse. 2002. The contribution of aquatic ecosystems and fisheries to food security and livelihoods: A research agend. Colombo, Sri Lanka.

Dudgeon, D., A.H. Arthington, M.O. Gessner, Z. Kwabata, D.J. Knowler, C. Leveque, R.J. Naiman, A. PrieurRichaed, D. Soto, M.L.J. Stiassny \& C.A. Sullivan. 2006. Fresh water biodiversity: importance, threats, status and conservation challenges. Biol. Rev. 81: 163-182.

Dufour, V., J.Y. Jouvenel \& R. Galzin. 1995. Study of a reef fish assemblage: comparison of population distribution between depths in protected and unprotected areas over one decade. Aquat. Liv. Res. 8: 17-25.

Duncan, J. \& J.L. Lockwood. 2001. Extinction in a field of bullets: a search for the cause in the decline of the world's freshwater fishes. Biol. Cons. 102: 97-105.

Dunne, T. \& L.B. Leopold. 1978. Water in Environmental Planning. W.H. Freeman, New York, USA.

Francour, P. 1991. The effect protection level on a coastal fish community at Scandola, Corsica. Revue d'Ecologie (Terre Vie) 46: 65-81.

Growns, I. \& P.C. Gehrke. 2003. A comparison of fish assemblage associated with different riparian vegetation types in the Hawksbury-epan River system. Fish Manag. Ecol. 10: 209-220.

Husain, A. 1983. Fish fauna of Corbett National Park, Uttaranchal. "CHEETAL". J.W.I.P.S. India 2: 39-42.

IUCN. 2010. IUCN Red List of Threatened Species (Downloaded: May 2011, www.iucnredlist.org).

Lake, P.S. 1980. Conservation, p. 163-173. In W.D. Williams (ed.). An ecological basis for water resource management. Australian University, Canberra, Australia.

Lakra, W.S. \& U.K. Sarkar. 2010. NBFGR-Marching ahead in cataloguing and conserving fish genetic resources of India. Fishing Chimes 30: 102-107.

Margules, R.C. \& L.R. Pressey. 2000. Systematic conservation planning. Nature 405: 243-253.

Millennium Ecosystem Assessment. 2005. Ecosystems and Human Well-being: Desertification Synthesis. World Resources Institute, Washington, D.C., USA.

Ministry of Environment and Forests. 2008. India. (Downloaded: May 2011, http:/www.moef.nic.in/report/ report.html).

Moilanen, A., J. Leathwick \& J. Elith. 2008. A method for spatial freshwater conservation prioritization. Freshwat. Biol. 53: 577-592.

McClanahan, T.R. \& A.B. Kaunda. 1996. Fishery recovery in a coral reef marine park and its effect on the adjacent fishery. Cons. Biol. 10: 1187-1199.

Mosquera, I., I.M. Cote, S. Jennings \& S. Reynolds. 2000. Conservation benefits of marine reserves for fish populations. Animal Cons. 3: 321-332.

Moyle, P.B. \& G.M. Sato. 1991. On the design of preserves to protect native fishes, p. 155-169. In W.L. Minckley \& J.E. Deacon (eds.). Battle against extinction: native fish management in the American West, The University of Arizona, Tucson, USA.

Conservation Assessment and Management Plan. 1998. Report. Workshop for freshwater fishes of India, organized by Zoo Outreach Organization and National Bureau of Fish Genetic Resources, Lucknow, held at NBFGR, September 1997. Zoo Outreach Organization, Coimbatore, India.

National Biodiversity Action Plan. 2008. Government of India. Ministry of Environment and Forests. F. No - J 22018/25/29/99-CS (BC)-Vol. VI.

Nel, J.L., D.J. Roux, R. Abell, P. Ashton, R.M. Cowling, J.V. Higgins, M. Thieme \& J.H. Viers. 2009. Progress and challenges in freshwater conservation planning. Aquatic Conserv: Mar. Freshw. Ecosyst. 19: 474-485.

Paller, M.H., M.J.M. Reichert, J.M. Dean \& J.C. Seigle. 2000. Use of fish community data to evaluate restoration success of a riparian stream. Ecol. Engin. 15: 171-187.

Raghavan, R., G. Prasad, P.H. Anvar Ali \& B. Pereira. 2008. Fish fauna of Chalakudy River, part of Western Ghats biodiversity hotspot, Kerala, India: patterns of distribution, threats and conservation needs. Biodivers. Conserv. 17: 3119-3131.

Saunders, D.L., J.J. Meeuwig \& A.C.J. Vincent. 2002. Freshwater Protected Areas: Strategies for Conservation. Conserv. Biol. 16: 30-41. 
Sarkar, U.K., D. Kapoor, S.K. Paul, A.K. Pathak, V.S. Basheer, P.K. Deepak, S.K. Srivastava \& L.K. Tyagi. 2007. Fish biodiversity in the water bodies of Samaspur bird sanctuary, Uttar Pradesh: Towards developing a freshwater aquatic sanctuary. J. Bombay Nat. Hist. Soc. 104: 51-54.

Sarkar, U.K. \& M.B. Bain. 2007. Priority habitats for the conservation of large river fish in the Ganges river basin. Aquatic Conserv: Mar. Freshw. Ecosyst. 17: 349- 359

Sarkar, U.K., A.K. Pathak \& W.S. Lakra. 2008. Conservation of freshwater fish resources of India: New approaches, assessment and challenges. Biodivers. Conserv. 17: 2495-2511.

Sarkar, U.K., B.K. Gupta \& W.S. Lakra. 2010. Biodiversity, ecohydrology, threat status and conservation priority of freshwater fishes of River Gomti, a tributary of River Ganga (India). Environmentalist 30: 3-17.

Shannon, C.E. \& W. Weiner. 1963. The Mathematical Theory of Communication. Urbana, Illinois, USA.
Sheldon, A.L. 1968. Species diversity and longitudinal succession in stream fishes. Ecology 49: 194-198.

Statistical Package for the Social Sciences (SPSS). 2006. SPSS 15.0 Base User's Guide. SPSS Inc., Chicago, USA.

Suski, C.D. \& S.J. Cooke. 2007. Conservation of aquatic resources through the use of freshwater protected areas: opportunities and challenges. Biodivers. Conserv. 16: 2015-2029.

Talwar, P.K. \& A.G. Jhingran. 1991. Inland fishes of India and adjacent, countries, New Delhi, India.

United Nations Environment Programme. 2005. World database on protected areas. United Nations Environment Programme and the World Conservation Monitoring Centre (Downloaded: May 2011, http://www.unep-wcmc.org/resources/publications/ UNEP_WCMC_bio_series/).

Vishwanath, W., W. Manojkumar \& L. Kosygin. 1998. Biodiversity of freshwater fishes of Manipur, India. Italian J. Zool. 65: 321-324. 